\title{
Profil Berpikir Logis Mahasiswa Calon Guru Matematika dalam Menyelesaikan Luas Daerah dengan Menggunakan Integral Lipat Dua
}

\author{
Swasti Maharani \\ Dosen Prodi Matematika IKIP PGRI Madiun \\ Email : swastimaharani@yahoo.com
}

\begin{abstract}
Abstrak. Penelitian ini bertujuan untuk mengetahui profil berpikir logis mahasiswa calon guru matematika dalam menyelesaikan masalah mencari luas daerah dengan integral lipat dua, yang meliputi memahami masalah, merencanakan pemecahan, menyelesaikan masalah sesuai langkah kedua dan memeriksa kembali hasil yang diperoleh.

Jenis penelitian yang digunakan adalah penelitian kualitatif. Subyek penelitian adalah enam mahasiswa calon guru matematika semester IV IKIP PGRI Madiun. Pengambilan subyek berdasarkan kemampuan mahasiswa yaitu berkemampuan tinggi, sedang, dan rendah. Teknik pengumpulan data dilakukan dengan metode tes, wawancara dan dokumen. Teknik keabsahan data dilakukan dengan triangulasi teknik yaitu membandingkan data hasil observasi, dokumentasi, tes dan wawancara. Data hasil penelitian dianalisis melalui reduksi data, penyajian data dan verifikasi data.
\end{abstract}

Hasil penelitian menyimpulkan bahwa: (1) Berpikir logis mahasiswa dalam memahami, merencanakan, menyelesaikan dan memeriksa kembali hasil yang diperoleh, mahasiswa berkemampuan tinggi pada tahap analisis membagi masalah ke dalam unsur atau sub masalah memiliki kecenderungan baik. Sedangkan, mahasiswa berkemampuan sedang dan rendah berkecenderungan cukup, (2) Berpikir logis mahasiswa dalam memahami, merencanakan, menyelesaikan dan memeriksa kembali hasil yang diperoleh, mahasiswa berkemampuan tinggi pada tahap analisis membuat diagram berpikir memiliki kecenderungan baik, sedangkan mahasiswa berkemampuan sedang dan rendah pada tahap analisis membuat diagram berpikir memiliki kecenderungan cukup, (3) Berpikir logis mahasiswa dalam merencanakan, menyelesaikan dan memeriksa kembali hasil yang diperoleh, mahasiswa berkemampuan tinggi pada tahap analisis mengumpulkan faktor memiliki kecenderungan baik, mahasiswa berkemampuan sedang kecenderungan cukup, dan mahasiswa berkemampuan rendah kecenderungan kurang, (4) Berpikir logis mahasiswa dalam merencanakan, menyelesaikan dan memeriksa kembali hasil yang diperoleh, mahasiswa berkemampuan tinggi, sedang dan rendah pada tahap analisis mencari hubungan memiliki kecenderungan baik, (5) Berpikir logis mahasiswa dalam merencanakan, menyelesaikan dan memeriksa kembali hasil yang diperoleh, mahasiswa berkemampuan tinggi, sedang dan rendah pada tahap analisis menemukan situasi memiliki kecenderungan baik, (6) Berpikir logis mahasiswa dalam menyelesaikan dan memeriksa kembali hasil yang diperoleh, mahasiswa berkemampuan tinggi dan sedang pada tahap analisis kesimpulan memiliki kecenderungan cukup. Sedangkan, mahasiswa berkemampuan rendah kecenderungan kurang, (7) Berpikir logis mahasiswa dalam memahami, merencanakan, menyelesaikan dan memeriksa kembali hasil yang diperoleh, mahasiswa berkemampuan tinggi dan sedang pada tahap analisis langkah-langkah sistematis memiliki kecenderungan cukup. Sedangkan, mahasiswa berkemampuan rendah kecenderungan kurang.

Kata Kunci : Berpikir, Berpikir Logis, Penyelesaian Masalah

\section{A. PENDAhULUAN}

Pendidikan berperan penting untuk mencerdaskan kehidupan bangsa. Salah satu ilmu yang berperan dalam pendidikan adalah matematika. Pembelajaran matematika diberikan kepada semua siswa mulai dari sekolah dasar hingga perguruan tinggi untuk membekali siswa dengan kemampuan 
berpikir logis, analitis, sistematis, dan kreatif serta kemampuan bekerja sama. Menurut Mahanta (2012) "The study of mathematics is considered to be very important in each and every country of the world. Students are required to learn mathematics which is considered as a basic education, since the skill of mathematics computation is essential in every walk of life." Belajar matematika dianggap sangat penting bagi setiap negara di dunia. Siswa diminta untuk belajar matematika yang dianggap sebagai pendidikan dasar, karena keterampilan perhitungan matematika sangat penting dalam setiap langkah kehidupan. Selanjutnya Amirali (2010) menambahkan "Mathematics is at the heart of many successful careers and successful lives for societal development, particularly in the extraordinary and accelerating change circumstances". Matematika adalah jantung dari banyak karir dan kehidupan yang sukses untuk pengembangan masyarakat, khususnya dalam perubahan yang luar biasa dan percepatan keadaan.

Kalkulus lanjut merupakan salah satu mata kuliah wajib bagi mahasiswa calon guru matematika. Di dalam kalkulus lanjut dibahas mengenai integral lipat dua dan tiga beserta aplikasinya. Lemahnya pemahaman mahasiswa terhadap konsep integral lipat dua akan mengakibatkan mahasiswa mengalami kesulitan menyelesaikan soal-soal yang berkaitan dengan mencari luas daerah dengan integral lipat dua. Hal ini merupakan suatu permasalahan dalam proses pembelajaran, sebab mahasiswa tersebut juga akan mengalami kesulitan dalam memahami materi berikutnya yaitu integral lipat tiga, sehingga akan mengakibatkan rendahnya prestasi belajar mahasiswa pada mata kuliah kalkulus lanjut.

Pada pokok bahasan mencari luas daerah dengan integral lipat dua dibutuhkan pemahaman yang logis yang lebih mendalam pada saat mengerjakan soal. Berpikir logis memainkan peranan penting dalam pembentukan struktur logika pengetahuan matematika. Ketepatan dan cara-cara formal merupakan hasil akhir dari aktivitas mengerjakan masalah matematika. Proses membangun pengetahuan matematika tanpa disadari menghasilkan pengenalan tentang kepastian atau ketidakpastian. Proses pengerjaan secara logis inilah yang penting untuk dikembangkan. Hal ini dikarenakan setiap mahasiswa memerlukan pengembangan logika dalam memecahkan masalah-masalah yang dihadapi sehingga dapat mengambil kesimpulan.

\section{B. METODE PENELITIAN}

Jenis penelitian kualitatif adalah suatu penelitian dengan data yang dianalisis berupa data kualitatif. Penelitian kualitatif bermaksud untuk memahami fenomena tentang apa yang dialami oleh subyek penelitian misalnya perilaku, persepsi, tindakan, dan lain-lain. Dalam penelitian ini, tidak ada hipotesis. Data yang dihasilkan adalah data deskriptif yang berupa kata-kata tertulis atau lisan.

Metode penelitian yang digunakan adalah metode deskriptif kualitatif. Penelitian deskriptif adalah penelitian yang memberikan gambaran dari suatu gejala yang ada dan menjawab pertanyaan-pertanyaan yang ada yang berhubungan dengan status (keadaan) subyek penelitian pada saat tertentu. Metode deskriptif sangat berguna untuk mendapatkan variasi permasalahan yang berkaitan dengan bidan pendidikan maupun tingkah laku manusia (Sukardi, 2012:157).

Pengambilan data menggunakan metode observasi, tes dan wawancara. Data yang diperoleh akan didiskripsikan atau diuraikan kembali kemudian akan dianalisis.

Dalam penelitian ini, subyek penelitian adalah mahasiswa calon guru matematika IKIP PGRI Madiun semester IV tahun akademik 2012/2013. Penelitian ini akan mengambil subyek penelitian sebanyak enam mahasiswa. Pengambilan subjek dengan 
pertimbangan, (a) kondusif dan mahasiswa mudah diajak kerja sama, (b) pertimbangan pembimbing akademik dan (c) nilai UTS.

Teknik pengumpulan data merupakan cara mengumpulkan data atau informasi yang dibutuhkan oleh peneliti. Dalam penelitian ini, peneliti menggunakan beberapa macam teknik untuk pengumpulan data yaitu tes, wawancara dan dokumen.

\section{Tes}

Tes merupakan serentetan pertanyaan atau latihan serta alat lain yang digunakan untuk mengukur keterampilan, pengetahuan inteligensi, kemampuan atau bakat yang dimiliki oleh individu atau kelompok (Suharsimi Arikunto, 2010: 192).

Adapun langkah-langkah yang dilakukan dalam membuat tes pada penelitian ini sebagai berikut.

a) Menyiapkan soal tes

b) Membagi soal tes kepada siswa

c) Mengawasi kerja siswa dalam menyelesaikan soal

d) Mengumpulkan hasil tes

e) Mengoreksi dan menskor hasil tes

f) Menganalisis hasil tes

Dalam penelitian dari hasil tes ini akan diperolah data bagaimana siswa dalam menyelesaikan soal dengan menghubungkan pengertian atau pengetahuan luas bangun datar yang dimilikinya secara logis.

\section{Wawancara}

Menurut Basrowi dan Suwandi (2008: 127) wawancara adalah percakapan dengan maksud tertentu oleh dua pihak, yaitu pewawancara (interviewer) sebagai pengaju/pemberi pertanyaan dan yang diwawancarai (interviewer) sebagai pemberi jawaban atas pertanyaan tersebut.

Dalam penelitian ini, teknik wawancara yang digunakan adalah wawancara tidak terstruktur atau mendalam. Wawancara tidak terstruktur adalah wawancara yang bebas dimana peneliti tidak menggunakan pedoman wawancara yang telah tersusun secara sistematis dan lengkap untuk pengumpulan datanya. Pedoman wawancara yang digunakan hanya berupa garis-garis besar permasalahan yang akan ditanyakan (Sugiyono, 2012:320).

Adapun langkah-langkah yang dilakukan peneliti dalam mengumpulkan data melalui wawancara adalah sebagai berikut:

a) Membuat pedoman wawancara mendalam.

Wawancara ini bersifat bebas atau tidak terencana, akan tetapi selalu terpusat pada satu pokok tertentu.

b) Wawancara dilaksanakan terhadap masing-masing mahasiswa secara terpisah dan butir pertanyaan dikembangkan dari hasil jawaban tes yang dilakukan oleh mahasiswa.

c) Menganalisis hasil wawancara sehingga diperoleh hal-hal yang berkaitan dengan berpikir logis mahasiswa dalam menyelesaikan soal luas benda dengan integral lipat dua khususnya benda bukan persegi panjang.

Dalam penelitian dari wawancara ini akan diperolah data bagaimana profil berpikir logis mahasiswa dalam menyelesaikan soal luas daerah bukan persegi panjang dengan integral lipat dua.

\section{Dokumen}

Studi dokumen merupakan pelengkap dari penggunaan metode observasi dan wawancara dalam penelitian kualitatif. Sebagian besar data yang tersedia yaitu berbentuk surat, laporan, rekaman dan foto. Sifat umum data ini tak terbatas pada ruang dan waktu sehingga memberi peluang kepada peneliti untuk mengetahui hal-hal yang pernah terjadi di waktu silam.

Untuk memperkuat hasil penelitan maka diperlukan dokumen atau data. Dalam penelitian ini, peneliti menggunakan data berbentuk laporan (raport), rekaman dan foto. 


\section{HASIL PENELITIAN DAN PEMBAHASAN}

Analisis jawaban tes dan wawancara yang dilakukan peneliti tentang profil berpikir logis mahasiswa calon guru matematika IKIP PGRI Madiun ditemukan kode-kode yang dapat disajikan dalam bentuk table 5.1 sebagai berikut:

Tabel 5.1 Pengkodean Profil Berpikir Logis Mahasiswa Calon Guru Matematika dalam Menyelesaikan Masalah Luas Daerah dengan Integral Lipat Dua

\begin{tabular}{|c|c|c|c|c|c|c|c|}
\hline S & \multicolumn{6}{|c|}{ Deskriptor Analisis Berpikir Logis } \\
\hline 1 & A1a & B1a & C1a & D1a & E1a & F1b & G1b \\
\hline 2 & A1a & B1a & C1a & D1a & E1a & F1b & G1b \\
\hline 3 & A1b & B1b & C1b & D1a & E1a & F1b & G1b \\
\hline 4 & A1b & B1b & C1b & D1a & E1a & F1b & G1b \\
\hline 5 & A1b & B1b & C1c & D1a & E1a & F1c & G1c \\
\hline 6 & A1b & B1b & C1c & D1a & E1a & F1c & G1c \\
\hline
\end{tabular}

\section{Keterangan:}

S : Subyek

Subyek 1 dan 2 adalah subyek

kemampuan tinggi

Subyek 3 dan 4 adalah subyek

kemampuan sedang

Subyek 5 dan 6 adalah subyek

kemampuan rendah

Berdasarkan sajian data analisis tes tulis dan wawancara tersebut, selanjutnya dilakukan penarikan simpulan tentang kemampuan pemecahan masalah luas daerah bukan persegi panjang dengan integral lipat dua yang terdiri dari 4 tahap langkah pemecahan masalah yaitu:

Tahap 1: Memahami masalah

Tahap 2: Merencanakan pemecahan masalah

Tahap 3: Menyelesaikan masalah sesuai rencana kedua

Tahap 4: Memeriksa kembali hasil yang diperoleh
Dari hasil analisis peneliti menemukan profil berpikir logis siswa yang beragam antara mahasiswa berkemampuan tinggi, sedang maupun rendah serta menghasilkan jawaban yang berbeda. Mereka memiliki kecenderungan untuk melewati tahapan berpikir logis sebagai berikut:

1. Berpikir logis mahasiswa dalam memahami, merencanakan, menyelesaikan dan memeriksa kembali hasil yang diperoleh, mahasiswa berkemampuan tinggi pada tahap analisis membagi masalah ke dalam unsur atau sub masalah memiliki kecenderungan yang baik dalam membagi masalah ke dalam unsur atau sub masalah secara relevan. Sedangkan, mahasiswa berkemampuan sedang dan rendah pada tahap analisis membagi masalah ke dalam unsur atau sub masalah memiliki berkecenderungan yang cukup dalam membagi masalah ke dalam unsur atau sub masalah secara relevan.

2. Berpikir logis mahasiswa dalam memahami, merencanakan, menyelesaikan dan memeriksa kembali hasil yang diperoleh, mahasiswa berkemampuan tinggi pada tahap analisis membuat diagram berpikir memiliki kecenderungan yang baik dalam membuat diagram masalah tetap pada posisinya, sedangkan mahasiswa berkemampuan sedang dan rendah pada tahap analisis membuat diagram berpikir memiliki kecenderungan yang cukup dalam membuat diagram masalah tetap pada posisinya.

3. Berpikir logis mahasiswa dalam merencanakan, menyelesaikan dan memeriksa kembali hasil yang diperoleh, mahasiswa berkemampuan tinggi pada tahap analisis mengumpulkan faktor memiliki kecenderungan yang baik dalam mengumpulkan faktor yang diketahui ke dalam satu wadah. Mahasiswa 
berkemampuan sedang pada tahap analisis mengumpulkan faktor memiliki kecenderungan yang cukup dalam mengumpulkan faktor yang diketahui ke dalam satu wadah. Sedangkan, mahasiswa berkemampuan rendah pada tahap analisis mengumpulkan faktor memiliki kecenderungan yang kurang dalam mengumpulkan faktor yang diketahui ke dalam satu wadah.

4. Berpikir logis mahasiswa dalam merencanakan, menyelesaikan dan memeriksa kembali hasil yang diperoleh, mahasiswa berkemampuan tinggi, sedang dan rendah pada tahap analisis mencari hubungan memiliki kecenderungan yang baik dalam mencari hubungan yang penting di antara faktor.

5. Berpikir logis mahasiswa dalam merencanakan, menyelesaikan dan memeriksa kembali hasil yang diperoleh, mahasiswa berkemampuan tinggi, sedang dan rendah pada tahap analisis menemukan situasi memiliki kecenderungan yang baik dalam menemukan situasi antara fakta, hubungan dan pengetahuan yang dimiliki.

6. Berpikir logis mahasiswa dalam menyelesaikan dan memeriksa kembali hasil yang diperoleh, mahasiswa berkemampuan tinggi dan sedang pada tahap analisis kesimpulan memiliki kecenderungan yang cukup dalam memahami kesimpulan yang dicapai. Sedangkan, mahasiswa berkemampuan rendah pada tahap analisis kesimpulan memiliki kecenderungan yang kurang dalam memahami kesimpulan yang dicapai.

7. Berpikir logis mahasiswa dalam memahami, merencanakan, menyelesaikan dan memeriksa kembali hasil yang diperoleh, mahasiswa berkemampuan tinggi dan sedang pada tahap analisis langkah-langkah sistematis memiliki kecenderungan yang cukup dalam mencari hubungan pokok dari masalah dengan langkah-langkah secara sistematis. Sedangkan, mahasiswa berkemampuan rendah pada tahap analisis langkah-langkah sistematis memiliki kecenderungan yang kurang dalam mencari hubungan pokok dari masalah dengan langkah-langkah secara sistematis

\section{PENUTUP}

\section{Kesimpulan}

Berdasarkan hasil penelitian dan pembahasan yang diperoleh, dapat di ambil suatu kesimpulan Profil Berpikir Logis mahasiswa calon guru matematika IKIP PGRI Madiun dalam menyelesaikan masalah luas daerah bukan persegi panjang dengan integral lipat dua sebagai berikut.

a. Berpikir logis mahasiswa dalam memahami, merencanakan, menyelesaikan dan memeriksa kembali hasil yang diperoleh, mahasiswa berkemampuan tinggi pada tahap analisis membagi masalah ke dalam unsur atau sub masalah memiliki kecenderungan baik. Sedangkan, mahasiswa berkemampuan sedang dan rendah berkecenderungan cukup.

b. Berpikir logis mahasiswa dalam memahami, merencanakan, menyelesaikan dan memeriksa kembali hasil yang diperoleh, mahasiswa berkemampuan tinggi pada tahap analisis membuat diagram berpikir memiliki kecenderungan baik, sedangkan mahasiswa berkemampuan sedang dan rendah pada tahap analisis membuat diagram berpikir memiliki kecenderungan cukup.

c. Berpikir logis mahasiswa dalam merencanakan, menyelesaikan dan memeriksa kembali hasil yang diperoleh, mahasiswa berkemampuan tinggi pada tahap analisis mengumpulkan faktor 
memiliki kecenderungan baik, mahasiswa berkemampuan sedang kecenderungan cukup, dan mahasiswa berkemampuan rendah kecenderungan kurang

d. Berpikir logis mahasiswa dalam merencanakan, menyelesaikan dan memeriksa kembali hasil yang diperoleh, mahasiswa berkemampuan tinggi, sedang dan rendah pada tahap analisis mencari hubungan memiliki kecenderungan baik.

e. Berpikir logis mahasiswa dalam merencanakan, menyelesaikan dan memeriksa kembali hasil yang diperoleh, mahasiswa berkemampuan tinggi, sedang dan rendah pada tahap analisis menemukan situasi memiliki kecenderungan baik.

f. Berpikir logis mahasiswa dalam menyelesaikan dan memeriksa kembali hasil yang diperoleh, mahasiswa berkemampuan tinggi dan sedang pada tahap analisis kesimpulan memiliki kecenderungan cukup. Sedangkan, mahasiswa berkemampuan rendah kecenderungan kurang.

g. Berpikir logis mahasiswa dalam memahami, merencanakan, menyelesaikan dan memeriksa kembali hasil yang diperoleh, mahasiswa berkemampuan tinggi dan sedang pada tahap analisis langkah-langkah sistematis memiliki kecenderungan cukup. Sedangkan, mahasiswa berkemampuan rendah kecenderungan kurang.

\section{DAFTAR PUSTAKA}

Albrecht, Karl. 1994. Daya Pikir. Semarang: Dahara Priz.
Amirali, M. 2010. Students' Conceptions of the Nature of Mathematics and Attitudes towards Mathematics Learning. Journal of Research and Reflections in Education, 4(1): 27-41.

Anisah Basleman dan Syamsu. 2011. Teori Belajar Orang Dewasa. Bandung: PT REMAJA ROSDAKARYA.

Basrowi dan Suwandi. 2008. Memahami Penelitian Kualitatif. Jakarta: PT RINEKA CIPTA.

Carole Wade dan Carol Tavris. 2007. Psikologi. Jakarta: ERLANGGA.

Departemen Pendidikan Nasional. 2008. Kamus Besar Bahasai Indonesia. Jakarta: PT Gramedia Pustaka Utama

Emzir. 2011. Metodologi Penelitian Kualitatif Analisis Data. Jakarta: PT. RAJA GRAFINDO PERSADA.

Herman, Hudojo. 2005. Pengembangan Kurikulum dan Pembelajaran Matematika. Malang: Malang University Press.

Mahanta, D. 2012. Achievement in Mathematics: Effect of Gender and Positive/Negative Attitude of Students. International Journal of Theoretical \& Applied Sciences, 4(2): 157-163.

Penduk Rintayati. 2011. Peningkatan Aktifitas Otak Kanan dan Otak Kiri, Creativitas Imagination, Intelektual Curiosity, Self Confidence dan Kesehatan Anak pada Pembelajaran Matematika Klas Rendah Melalui Metode Jarimatika. Solo: UNS

Santrock, John W. 2009. Psikologi Pendidikan (Edisi 3). Jakarta: Salemba Humanika.

Sugiyono. 2012. Metode Penelitian Kuantitaif Kualitatif dan $R$ \& D. Bandung: Alfabeta.

Suharsimi Arikunto. 2010. Prosedur Penelitian Suatu Pendekatan Praktik (Edisi Revisi 2010). Jakarta:Rineka Cipta.

Sukardi. 2012. Metode Penelitian Pendidikan. Jakarta: Bumi Aksara.

Surajiyo, Sugeng Astanto dan Sri Andiani. 2006. Dasar-dasar Logika. Jakarta: PT Bumi Aksara. 